\title{
PENGARUH PENDEKATAN OPENENDED TERHADAP KEMAMPUAN BERPIKIR KREATIF DAN KEPERCAYAAN DIRI PADA MATERI SPLDV DI KELAS X SMK PUTRA ANDA BINJAI
}

\author{
Lilis Saputri, Dira Puspita Sari \\ STKIP Budidaya Binjai
}

\begin{abstract}
ABSTRAK
Tujuan penelitian ini adalah untuk mengetahui pengaruh pendekatan open-ended terhadap kemampuan berpikir kreatif dan kepercayaan diri. Peneliti ini merupakan penelitian eksperimen semu, dengan desain penelitian pretest and post-test control group design. Populasi adalah siswa kelas X SMK Putra Anda Binjai, sedangkan sampel dalam penelitian ini terdiri dari dua kelas. Sampel pada kelompok eksperimen berjumlah 23 orang. Data dalam kelompok kontrol berjumlah 23 orang. Data dalam penelitian ini dianalisis menggunakan uji regresi rederhana. Tes yang digunakan tes kemampuan berpikir kreatif yang dinyatakan validitor dan siswa data valid . dengan data normalitas 8,83 normal, data homogenitas 0,917 Homogen, dan data hipotesis 0,925 normal. Dengan rata-rata tes kemampuan berpikir kreatif kelas eksperimen sebelum dan sesudah pembelajaran adalah 67,56 dan 68,41. Pengujian hipotesis dalam penelitian ini menggunakan uji-r, setelah dilakukan perhitungan diperoleh nilai $r_{\text {hitung }}$ kemampuan berpikir kreatif siswa kelas eksperimen adalah 0,925 sedangkan $r_{\text {tabel }}$ 0,396, Pengujian hipotesis dalam uji-r juga dilakukan perhitungan diperoleh nilai $r_{\text {hitung }}$ kepercayaan diri siswa kelas eksperimen adalah 0,907 sedangkan $r_{\text {tabel }}$ 0,396. Maka dapat disimpulakan bahwa terdapat pengaruh pendekatan open-ended terhadap kemampuan berpikir kreatif dan kepercayaaan diri pada materi SPLDV dikelas X SMK Putra Anda Binjai.
\end{abstract}

Kata kunci : pendekatan open-ended, berpikir kreatif dan kepercayaan diri

\section{PENDAHULUAN}

Matematika merupakan ilmu abstrak. Sehingga untk memahaminya diperlukan berpikir yang logis. Selain itu diperlukan pula ketekunan dan semangat siswa untuk memahami pelajaran matematika. Karena keabstrakkannya itu membuat sebagian siswa sulit untuk memahaminya. Akibatnya banyak beranggapan matematika sebagian pelajaran yang sangat sulit dan rumit untuk dipelajari.

Banyak faktor yang menyebabkan siswa sulit dalam memahami matematika diantaranya karena matematika itu berkesan dengan objek-objek yang abstrak dan mrupakan bahasa simbolis. Berhandi juga mengatakan bahwa "Kegiatan matematika adalah kegiatan yang didalamnya terjadi proses pengabstrakkan dan pengalaman nyata dalam kehidupan sehari-hari kedalam dunia matematika atau sebaliknya"

Pembelajaran matematika memiliki fungsi sebagai sarana untuk mengembangkan kemampuan berpikir kreatif, kritis, logis, kepercayaan diri dan bekerja sama yang diperlukan siswa dalam kehidupan modern sebagaimana tercantum dalam salah satu tujuan pembelajaran matematika dalam KTSP bahwa melalui pembelajaran matematika sswa dapat mengembangkan kreatif-kreatif yang melibatkan imajinasi, intuisi, dan penemuan dengan mengembangkan pemikiran divergen, orisinil. 
Peneliti telah melakukan tes pendahuluan kepada siswa kelas X SMK Putra Anda Binjai dengan satu soal untuk mengetahui kemampuan berpikir kreatif siswa dalam mengerjakan soal sebagai berikut:
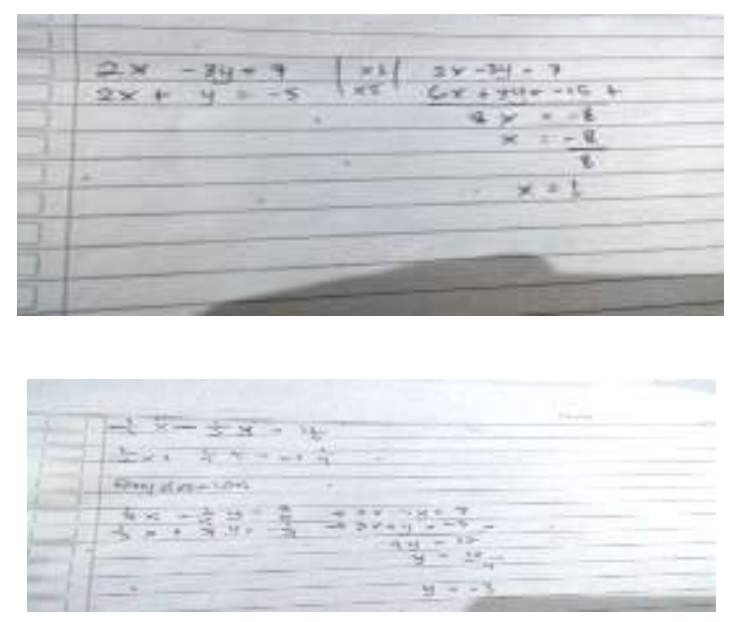

Gambar 1. Observasi Awal

Siswa terlalu pakum dalam menyelesaikan soal dalam beragam strategi karena kurangnya berpikir kreatif sehinggasiswa hanya bisa menjawab dengan secara. Kurangnya siswa dalam berpikir lancar untuk menimbulkan banyak cara. Siswa belum dapat cara baru untuk menyelesaikan soal. Siswa belum dapat menjawab soal dengan jelas atau belum maksimal dalam mengerjakan soal kurangnya keseriusan siswa untuk belajar sehingga untuk menjawab soal belum terperinci jelas.

Rendahnya kemampuan berpikir kreatif dan kepercayaan diri juga dapat berimplikasi pada rendahnya prestasi siswa, kenyataannya, model penyajian materi atau proses belajar matematika masa kini digambarkan dalam hasil penelitian yakni sebagian siswa tampak mengikuti dengan baik setiap penjelasan atau informasi dari gurunya, tetapi para siswa tersebut sangat jarang mengajukan pertanyaan kepada gurunya, sehingga yang terjadi guru asyik sendiri menjelaskan apa-apa yang telah disiapkannya, Menurut Rahmat : Apabila orang merasa rendah diri, ia akan mengalami kesulitan untuk mengkomunikasikan gagasannya pada orang lain, dan menghindar untuk berbicara didepan umum atau ingin bertanya kepada gurunya , karena takut orang lain menyalahkannya. Kepercayaan diri siswa diasumsikan dapat mempengaruhi tingkat kecemasan mereka didalam berbicara di depan umum.

Maka untuk merangsang kemampuan berpikir kreatif dan kepercayaan diri siswa, kegiatan pembelajaran harus membawa siswa dalam menjawab permasalahan dengan banyak cara dengan menyuruh siswa mengerjakan soal maju kedepan untuk mempresentasikan jawabannya agar terlatih rasa kepercayaan diri dan pengalaman siswa dalam menemukan sesuatu yang baru, pembelaran yang memberka problem terbuka atau memberikan multi jawaban yang benar disebut pembelajaran dengan pendekatan open-ended. Sehingga dengan menggunakan pendekatan open-ended dalam pembelajaran matematika, akan merangsang kemampuan berpikir kreatif dan kepercayaan diri siswa karena dalam pendekatan tersebut siswa diberikan masalah-masalah yang terbuka yang dapat memberikan keleluasaan siswa dalam berpikir dalam menyelesaikan suatu masalah. 
Salah satu pendekatan dalam pembelajaran matematika yang dapat memberikan keleluasaan siswa untuk berpikir secara aktif, kreatif juga dapat membuat siswa berani untuk mempresentasikan pendapatnya didepan umum tanpa harus malu-malu adalah pendekatan open-ended. Pendekatan open-ended bermanfaat untuk meningkatkan cara berpikir siswa dan meningkatkankn kepercayaan diri siswa. pendekatan open-ended merupakan salah satu permasalahan yang memiliki penyelesaian yang lebih dari satu pendekatan yang membantu siswa melakukan pemecahan masalah secara kreatif.

Pengertian open-ended menurut shimada adalah pendekatan pembelajaran yang menyajikan suatu permasalahan yang memiliki penyeesaian yang lebih dari satu. Pendekatan open-ended ini memberikan kesempatan kepada siswa untuk memperoeh pengetahuan, pengalaman menemukan, mengenali dan memecahkan masalah dengan beberapa teknik. Dalam proses ini menggunakan soal-soal open-ended sebagai alat pembelajarannya.

Berdasarkan kenyataan bahwa tingkat kemampuan berpikir kreatif dan rasa kepercayaan diri anak-anak Indonesia yang masih rendah serta arti dan peranan penting berpikir kreatif dalam kehidupan, dengan demikian perlu memberikan sebuah lingkungan berlajar bagi siswa-siswa sekolah yang dapat mengembangkan kemampuan kreatif dan kepercayaan diri siswa . mengacu pada pendapat bahwa pendekatan open-ended yang dapat diperkirankan bahwa pendekatan ini dapat menjadi fasilitator dalam Mengembangkan kemampuan berpikir kreatif dan kepercayaan diri siswa .

\section{METODE}

Jenis Metode dalam penelitian ini adalah ekperimen dalam bentuk pre-experimental designs (non designs). Desain penelitian yang digunakan dalam penelitian eksperimen ini adalah One Group Pretest-Posttest Design, adapun gambaran mengenai rancangan One Group Pretest-Posttest Design menurut Sugiyono (2009 : 112) sebagai berikut:

$$
\mathrm{O}_{1} \quad \mathrm{X} \quad \mathrm{O}_{2}
$$

Keterangan :

$\mathrm{O}_{1} \quad$ : Nilai pretest (sebelum diberi diklat)

$\mathrm{O}_{2} \quad$ : Nilai posttest (sesudah diberi diklat

\section{HASIL DAN PEMBAHASAN}

\section{Deskripsi Hasil Kemampuan Berpikir Kreatif Dan Kepercayaan Diri Hasil Berpikir Kreatif}

Pada bagian ini akan dideskripsikan hasil Pretest dan Post-test siswa pada masingmasing kelas, yaitu kelas eksperimen dan kelas kontrol. Berdasarkan hasil tes dan angket yang diberikan kepada siswa, baik diawal maupun diakhir pembelajaran diperoleh dua kelompok nilai, yaitu kelomok nilai kelas ekperimen dan kelompok nilai kelas kontrol. Kelompok nilai eksperimen adalah hasil tes kemampuan berpikir kreatif dan angket kepercayaan diri dengan pendekatan Open-Ended, sedangkan kelompok nilai kelas kontrol 
adalah hasil tes kemamuan berpikir kreatif dan angket kepercayaan diri yang diajarkan dengan model kooperatif tipe STAD.

Menggambarkan bahwa berdasarkan hasil Post-test yang diujikan skepada 23 orang didapatkan hasil bahwa nilai tertinggi dan terendah dari kelas ksperimen secara berturut-turut adalah 100 dan 50 dengan rata-rata nilai pada kelas eksperimen adalah 68,61. Sedangkan nilai tertinggi dan terendah dari kelas kontrol secara berturut-turut 90 dan 50 dengan ratarata nilai pada kelas kontrol adalah 68,41. Secara visual hasil tes kemampuan berpikir kreatif siswa sebelum dan sesudah dapat dinilai dari grafik berikut :

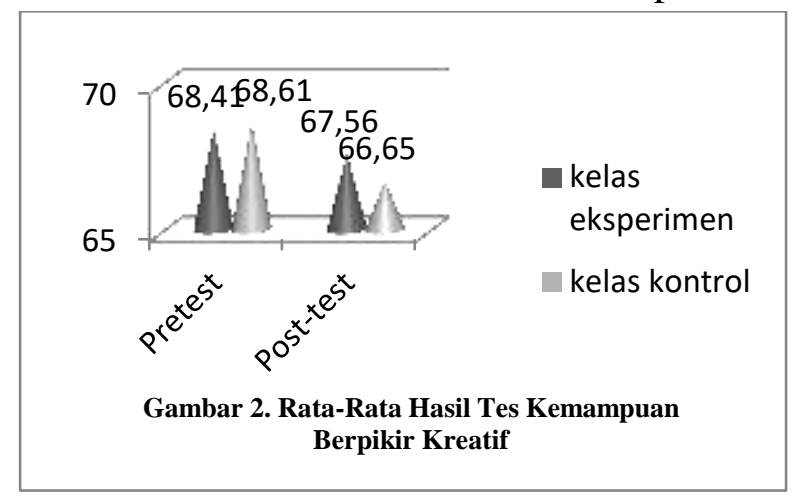

Gambar 2. menggambarkan bahwa sebelum diajar dengan pendekatan Open-Ended nilai rata-rata siswa pada kelas eksperimen 67,56, sedangkan nilai rata-rata siswa pada kelas kontrol yaitu 67,73. Ini berarti nilai rata-rata siswa dikelas eksperimen lebih rendah dari nilai rata-rata siswa kelas kontrol. Tetapi setelah diajarkan dengan pendekatan Open-Ended nilai rata-rata siswa pada kelas eksperimen mengalami peningkatan yang signifikan menjadi 68,61 , sedangkan nilai rata-rata siswa pada kelas kontrol tidak terlalu meningkat 68,41 . Ini berarti setelah melalkukan pembelajaran dengan pendekatan Open-Ended, nilai rata-rata siswa dikelas eksperimen lebih tinggi dari nilai rata-rata siswa kelas kontrol.

\section{Hasil Angket Kepercayaan Diri}

Pada bagian ini akan dideskripsikan hasil angket kepercayaan diri pada masingmasing kelas yaitu kelas eksperimen dan kontrol. Berdasarkan hasil angket yang diberikan pada siswa, baik berawal maupun diakhir pembelajaran diperoleh dua kelompok nilai. Yaitu kelompok nilai eksperimen dan kelompok kelas kontrol. Kelompok nilai eksperimen adalah angket kepercayaan diri dengan pendekatan open-ended, sedangkan kelompok niai kelas kontrol adalah hasil angket kepercayaan diri yang diajarkan menggunakan model kooperatif tife STAD.

Menggambarkan bahwa berdasarkan hasil Angket kepercayaan diri yang diujikan skepada 23 orang didapatkan hasil bahwa nilai tertinggi dan terendah dari kelas ksperimen secara berturut-turut adalah 100 dan 50 dengan rata-rata nilai pada kelas eksperimen adalah 69,61. Sedangkan nilai tertinggi dan terendah dari kelas kontrol secara berturut-turut 90 dan 50 dengan rata-rata nilai pada kelas kontrol adalah 68,41. Secara visual hasil tes kemampuan kepercayaan diri siswa sebelum dan sesudah dapat dinilai dari grafik berikut : 


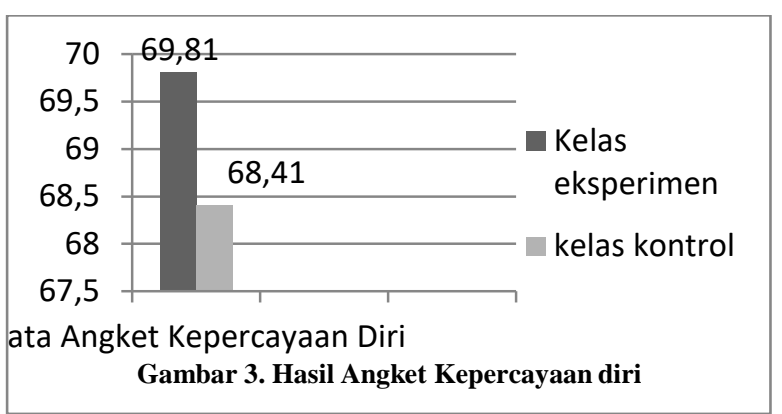

Gambar.3. menggambarkan bahwa sebelum diajar dengan pendekatan Open-Ended nilai angket kepercayaan diri pada kelas eksperimen 69,81, sedangkan nilai angket kepercayaan diri siswa pada kelas kontrol yaitu 68,41, setelah diajarkan dengan pendekatan Open-Ended Ini berarti nilai angket siswa dikelas eksperimen lebih tinggi dari nilai angket di kelas kontrol.

\section{Hasi Uji Prasyarat Analisis}

\section{Kemampuan Berpikir Kreatif}

\section{a. Uji Normalitas}

Untuk normalitas dilakukan untuk mengetahui apakah populasi dalam penelitian ini berdistribusi normal atau tidak. Pada tabel dibawah ini disajikan hasil uji normalitas dari hasil post-test siswa pada masing-masing kelompok kelas yang dihitung dengan menggunakan metode Chi Kuadrat, hasil nya adalah sebagai berikut

Menggambarkan bahwa hasil perhitungan normalitas post-test pada kedua kelas menunjukan bahwa data beridtribusi normal. Berdasarkan perhitungan dengan menggunakan metode Chi Kuadrat diperoleh hasil $\boldsymbol{x}^{\mathbf{2}}$ hitung pada kelas eksperimen yang menggunakan pendekatan pembelajaran Open-Ended adalah 8,45, sedangkan nilai $\boldsymbol{x}^{2}$ tabel adalah 11,070. Dengan demikian $\boldsymbol{x}^{\mathbf{2}_{\text {hitung }}}<\boldsymbol{x}^{2}$ tabel , ini berarti $\mathrm{H}_{0}$ diterima dan $\mathrm{H}_{\mathrm{a}}$ ditolak, sehingga dapat disimpulkan bahwa data berdistribusi normal. Begitu pula hasil perhitungan pada kelas kontrol yang menggunakan Model Kooperatif tipe STAD, dari perhitungan diperoleh hasil

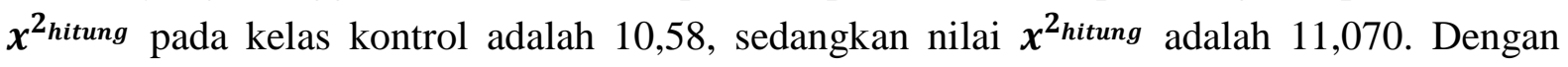
demikian $\boldsymbol{x}^{\mathbf{2}_{\text {hitung }}}<\boldsymbol{x}^{\mathbf{2} \text { tabel }}$, ini berarti data berdistribusi normal.

\section{b. Uji Homogenitas}

Setelah kedua kelas sampel pada penelitian ini dinyatakan berasal dari populasi yang berdistribusi normal, maka selanjutnya menguji homogenitas varians kedua sampel tersebut. Uji Homogenitas dilakukan untuk mengetahui apakah populasi penelitian memiliki variasi yang sama atau tidak. Berikut ini merupakan deskripsi hasil dari uji homogenitas terhadap hasil post-test siswa pada kedua kelas. Menggambarkan bahwa hasil perhitungan homogenitas post-test pada kedua kelas menunjukan bahwa populasi homogeny. Berdasarkan perhitungan diperoleh $\boldsymbol{x}^{\mathbf{2}}$ itung adalah 0,831, sedangkan nilai $\boldsymbol{x}^{\mathbf{2}}$ tabel dengan taraf signifikan 5\% adalah 2,041. Dengan demikian dapat disimpulkan bahwa populasi homogeny.

\section{Kepercayaan Diri}

\section{a. Uji Normalitas}

Untuk normalitas dilakukan untuk mengetahui apakah populasi dalam penelitian ini berdistribusi normal atau tidak. Pada tabel dibawah ini disajikan hasil uji normalitas dari hasil 
angket kepercayaan diri siswa pada masing-masing kelompok kelas yang dihitung dengan menggunakan metode Chi Kuadrat.

Menggambarkan bahwa hasil perhitungan normalitas angket kepercayaan diri pada kelas eksperimen dan kelas kontrol menunjkan bahwa data berdistribusi normal. Brdasarkan perhitungan dengan menggunakan metode Chi Kuadrat diperoleh hasil $\boldsymbol{x}^{\mathbf{2}}$ hitung pada kelas eksperimen adalah 6,95, sedangkan nilai $\boldsymbol{x}^{\mathbf{2}_{\text {tabel }}}$ adalah 11,070. Dengan demikian $\boldsymbol{x}^{\mathbf{2} \text { hitung }}<$ $x^{2}$ tabel, ini berarti $\mathrm{H}_{0}$ diterima dan $\mathrm{H}_{\mathrm{a}}$ ditolak, sehingga dapat disimpulkan bahwa data brdistribusi normal. Begitu pula hasil perhitungan pada kelas kontrol, dari perhitungan diperoleh hasil $\boldsymbol{x}^{\mathbf{2}_{\text {hitung }}}$ pada kelas kontrol adalah 6,45, sedangkan nilai $\boldsymbol{x}^{\mathbf{2} \text { tabel }}$ adalah 11,070. Dengan demikian $\boldsymbol{x}^{\mathbf{2}_{\text {hitung }}}<x^{\mathbf{2} \text { tabel }}$, ini berarti data berdistribusi normal.

\section{b. Uji Homogenitas}

Setelah kedua kelas sampel pada penelitian ini dinyatakan berasal dari populasi yang berdistribusi normal, maka selanjutnya menguji homogenitas varians kedua sampel tersebut. Uji Homogenitas dilakukan untuk mengetahui apakah populasi penelitian memiliki variasi yang sama atau tidak. Berikut ini merupakan deskripsi hasil dari uji homogenitas terhadap hasil angket kepercayaan diri siswa pada kedua kelas menggambarkan bahwa hasil perhitungan homogenitas Angket kepercayaan diri menunjukan bahwa populasi penelitian homogen. Berdaarkan perhitungan diperoleh hasil $\boldsymbol{x}^{\mathbf{2}_{\text {hitung }}}$ adalah 0,917 , sedangkan nilai $\boldsymbol{x}^{\mathbf{2}_{\text {tabel }}}$ dengan taraf signifikan 5\% adalah 2,014. Dengan demikian $\boldsymbol{x}^{\mathbf{2} \text { hitung }}<\boldsymbol{x}^{\mathbf{2} \text { tabel }}$, ini berarti $\mathrm{H}_{0}$ diterima dan $\mathrm{H}_{\mathrm{a}}$ ditolak, dengan demikian dapat disimpulkan bahwa populasi homogen.

\section{Hasil Uji Analisis Regresi Sederhana \\ a. Kemampuan Berpikir Kretif}

Bagian ini mendeskripsikan tentang pencapaian pada kelas eksperimen, yaitu kelas mendapatkan perlakuan. pembelajaran dengan menggunakan pendekatan Open-Ended berdasarkan hasil pretest dan post-test yang telah dikerjakan. Pengujuan dilakukan dengan mengunakan uji regresi.

Menggambarkan bahwa dari hasil perhitungan yang dilakukan diperoleh hasil persamaan regresi $\widehat{\boldsymbol{Y}}=\mathbf{0 , 0 2}+\mathbf{2 , 6 0 x}$. sedangkan hasil jumlah kuadrat total dengan dk adalah 11078, jumlah kuadrat koefisien(a) dengan dk 1 adalah 108264,52 dan jumlah kuadrat Koefisien (b a) dengan dk 1 adalah 2175,4408. Setelah jumlah kuadrat total, jumlah kuadrat koefisien (a), dan jumlah kuadrat koefisien (b|a) diketahui selanjutnya dihitung $\mathrm{F}$ dengan rumus $=\frac{S_{r e g}^{2}}{S_{r e s}^{2}}$. dari hasil perhitungan diperoleh hasil nilai $\mathrm{F}$ yaitu 37,87 , dan ini merupakan nilai keberartian dari nilai pretest dan post-test pada kelas eksperimen.

Setelah nilai keberartian diketahui, selanjutnya akan dicari nilai linieritasnya. Sebelm itu akan dicari terlebih dahulu nilai jumlah kuadrat sisa, kadrat tuna cocok, dan jumlah kuadrat galat. Dari hasil perhitungan diperoleh hasil jumlah kuadrat sisa dengan dk 21 adalah99361,96 dan kuadrat total 66,73, jumlah kuadrat tuna cocok dengan dk 6 adalah 217,53 dengan kuadrat totalnya adalah 79,96, sedangkan jumlah kuadrat galat dengan dk 17 adalah 97186,52 dengan kuadrat totalnya adalah 63,81 . Setelah jumlah kuadrat sisa, jumlah 
kuadrat tuna cocok dan jumlah kuadrat galat diketahui selanjuya dihitung nilai $\mathrm{F}$ dengan rumus $F=\frac{S_{r e g}^{2}}{S_{r e s}^{2}}$. Dari hasil perhitungan diperoleh hasil nilai $F$ yaitu 1,25 , dan ini merupakan nilai linieritas dari nilai pretest dan post-test pada kelas eksperimen.

\section{Uji Keberartian}

Untuk menguji hiptesis nol, dipakai statistic $F=\frac{S_{r e g}^{2}}{S_{r e s}^{2}}$ ( Fhitung ), selanjutnya dibandigkan dengan harga $F_{\text {tabel }}$ dengan dk pembilang $=1$ dan $\mathrm{dk}$ penyebut 21 . Dari hasil penelitian terdapat hasil bahwa nilai $\mathrm{Ha}: \mathrm{b} \neq 0$ adalah 2,60 .

Dari hasil perhitungan tersebut diperoleh nilai $F_{\text {hitung }}=37,87$, sedangkan harga $F_{\text {tabel }}(1,21)=1,14$ untuk taraf signifikan $5 \%$ dengan demikian harga $F_{\text {hitung }}>F_{\text {tabel }}$ berarti $\mathrm{H}_{0}$ ditolak dan $\mathrm{H}_{\mathrm{a}}$ diterima. Kesimpulan adalah koefisien arah regresi berarti $b \neq 0$ )

\section{Uji Linieritas}

Untuk menguji linieritas, dipakai statistic $F=\frac{S_{r e g}^{2}}{S_{r e s}^{2}}$ ( Fhitung ), selanjutnya dibandingkan dengan $F_{\text {tabel }}$ dengan dk pembilang 6 dan dk penyebut $=17$, Dari hasil penelitian terdapat hasil bahwa nilai $\mathrm{H}_{0}: a=0$ adalah 0,02 .

Hasil dari perhitungan tersebut diperoleh nilai $F_{\text {hitung }}=1,25$, sedangkan harga $F_{\text {tabel }}(6,17)=2,46$ untuk taraf signifikan dengan demikian harga $F_{\text {hitung }}<F_{\text {tabel }}$ berarti $\mathrm{H}_{0}$ diterima dan $\mathrm{H}_{\mathrm{a}}$ ditolak, dengan demikian kesimpulannya adalah regresi linier.



Gambar.4.menggambarkan bahwa hasil uji linieritas yang dilakukan pada kelas eksperimen yang diajarkan dengan pendekatan Open-Ended menunjukan garis lurus. Ini berarti hasil perhitungan nilai pretest dan post-test siswa membentuk regresi yang linier.

\section{Uji Hipotesis}

Perhitungan uji hipotesis dilakukan untuk mengetahui ada atau tidaknya pengaruh dalam pembelajaran dengan menggunakan pendekatan open-ended terhadap kemampuan berpikir kreatif siswa. Pengujian hipotesis dala enelitian ini menggunakan uji-r dengan menggunakan data hasil kemampuan berpikir kreatif yang diperoleh siswa, yaitu data hasil pretest dan post-test.

Setelah dilakukannya perhitungan dengan menggunakan uji-r maka diperoleh nilai $r_{\text {hitung }}=0,925$ kemidian nilai tersebut dibandingkan dengan nilai $r_{\text {tabel }}$ dengan $\mathrm{n}=23$ dan taraf signifikan $5 \%=0,396$. Karena harga $r_{\text {hitung }}>r_{\text {tabel }}$ maka $\mathrm{H}_{0}$ ditolak dan $\mathrm{H}_{\mathrm{a}}$ diterima, 
dengan demikian dapat terdapat pengaruh antara pendekatan open-ended dan kemampuan berpikir kreatif.

\section{b. Kepercayaan Diri}

Bagian ini mendeskripsikan tentang pencapaian pada kelas eksperimen, yaitu kelas mendqapatkan perlakuan pembelajaran dengan menggunakan pendekatan Open-Ended berdasarkan hasil angket kepercayaan diri yang telah dikerjakan.

Menggambarkan bahwa dari hasil perhitungan yang dilakukan diperoleh hasil persamaan regresi $\widehat{\boldsymbol{Y}}=\mathbf{0 , 0 3}+\mathbf{2 , 6 3 x}$. sedangkan hasil jumlah kuadrat total dengan dk adalah 11078 , jumlah kuadrat koefisien(a) dengan dk 1 adalah 108264,52 dan jumlah kuadrat Koefisien (b a) dengan dk 1 adalah 2175,4408. Setelah jumlah kuadrat total, jumlah kuadrat koefisien (a), dan jumlah kuadrat koefisien (b $\mid$ a) diketahui selanjutnya dihitung $\mathrm{F}$ dengan rumus $=\frac{S_{r e g}^{2}}{S_{r e s}^{2}}$. dari hasil perhitungan diperoleh hasil nilai $\mathrm{F}$ yaitu 37,89 , dan ini merupakan nilai keberartian dari nilai Angket kepecayaan diri pada kelas eksperimen.

Setelah nilai keberartian diketahui, selanjutnya akan dicari nilai linieritasnya. Sebelm itu akan dicari terlebih dahulu nilai jumlah kuadrat sisa, kadrat tuna cocok, dan jumlah kuadrat galat. Dari hasil perhitungan diperoleh hasil jumlah kuadrat sisa dengan dk 21 adalah99361,96 dan kuadrat total 66,73, jumlah kuadrat tuna cocok dengan dk 6 adalah 217,53 dengan kuadrat totalnya adalah 79,96, sedangkan jumlah kuadrat galat dengan dk 17 adalah 97186,52 dengan kuadrat totalnya adalah 63,81. Setelah jumlah kuadrat sisa, jumlah kuadrat tuna cocok dan jumlah kuadrat galat diketahui selanjuya dihitung nilai $\mathrm{F}$ dengan rumus $F=\frac{S_{r e g}^{2}}{S_{r e s}^{2}}$. Dari hasil perhitungan diperoleh hasil nilai $F$ yaitu 1,25 , dan ini merupakan nilai linieritas dari nilai angket kepercayaan diri pada kelas eksperimen.

\section{Uji Keberartian}

Untuk menguji hiptesis nol, dipakai statistic $F=\frac{S_{r e g}^{2}}{S_{r e s}^{2}}\left(F_{\text {hitung }}\right)$, selanjutnya dibandigkan dengan harga $F_{\text {tabel }}$ dengan dk pembilang $=1$ dan dk penyebut 21 . hasil penelitian terdapat hasil bahwa nilai Ha: $b \neq 0$ adalah 2,63. Untuk Dari hasil perhitungan tersebut diperoleh nilai $F_{\text {hitung }}=37,89$, sedangkan harga $F_{\text {tabel }}(1,21)=1,14$ untuk taraf signifikan 5\% dengan demikian harga $F_{\text {hitung }}>F_{\text {tabel }}$ berarti $\mathrm{H}_{0}$ ditolak dan $\mathrm{H}_{\mathrm{a}}$ diterima. Kesimpulan adalah koefisien arah regresi berarti $b \neq 0$ ).

\section{Uji Linieritas}

Untuk menguji linieritas, dipakai statistic $F=\frac{S_{r e g}^{2}}{S_{\text {res }}^{2}}\left(F_{\text {hitung }}\right)$, selanjutnya dibandingkan dengan $F_{\text {tabel }}$ dengan dk pembilang 6 dan dk penyebut $=17$, Dari hasil penelitian terdapat hasil bahwa nilai $\mathrm{H}_{0} \quad: a=0$ adalah 0,03 . Hasil dari perhitungan tersebut diperoleh nilai $F_{\text {hitung }}=1,25$, sedangkan harga $F_{\text {tabel }}(6,17)=2,46$ untuk taraf signifikan dengan demikian harga $F_{\text {hitung }}<F_{\text {tabel }}$ berarti $\mathrm{H}_{0}$ diterima dan $\mathrm{H}_{\mathrm{a}}$ ditolak, dengan demikian kesimpulannya adalah regresi linier. Secara visual hasil uji linieritas angket kepercayaan diri dapat dilihat pada gambar barikut : 


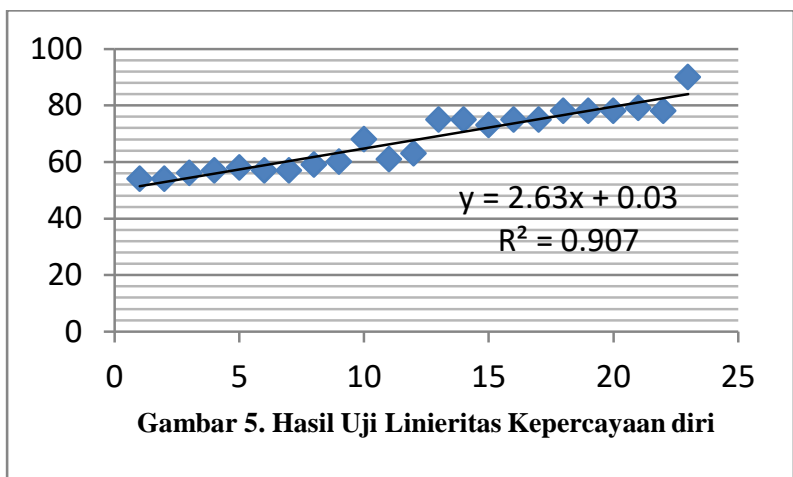

Gambar 5. menggambarkan bahwa hasil uji linieritas yang dilakukan pada kelas eksperimen yang diajar dengan pendekatan open-ended membentuk grafik garis lurus. Ini berarti hasil perhitungan nilai angket kepercayaan diri siswa membentuk regresi yang linier.

\section{Uji Hipotesis}

Perhitungan uji hipotesis dilakukan untuk mengetahui ada atau tidaknya pengaruh dalam pembelajaran dengan menggunakan pendekatan open-ended terhadap kemampuan berpikir kreatif siswa. Pengujian hipotesis dala enelitian ini menggunakan uji-r dengan menggunakan data hasil kemampuan berpikir kreatif yang diperoleh siswa, yaitu data hasil post-test.

Setelah dilakukannya perhitungan dengan menggunakan uji-r maka diperoleh nilai $r_{\text {hitung }}=0,907$ kemidian nilai tersebut dibandingkan dengan nilai $r_{\text {tabel }}$ dengan $\mathrm{n}=23$ dan taraf signifikan 5\%=0,396. Karena harga $r_{\text {hitung }}>r_{\text {tabel }}$ maka $\mathrm{H}_{0}$ ditolak dan $\mathrm{H}_{\mathrm{a}}$ diterima, dengan demikian dapat terdapat pengaruh antara pendekatan open-ended dan kemampuan berpikir kreatif.

\section{Pembahasan}

Proses pembelajaran dengan menggunakan pendekatan open-ended siswa lebih aktif, siswa jadi lebih bertanggung jawab terhadap tugasnya, siswa menjadi lebih tahu inti dari pembelajaran ang mereka lakukan dengan adanya kesimpulan, siswa menjadi lebih mampu dalam menyelesaikan masalah-masalah yang berkaitan dengan materi, serta kesan senang dlam pembelajran lebih terlihat. Sedangakn pembelajran dengan menggunakan pmbelajaran kooperatif tipe STAD siswa menjadi kurang aktif, banyak siswa yang menjukkan sikap bosan karena harus mengerjakan soal, terlebih lagi bagi siswa yang memiliki kemampuan rendah, meskipun dalam pelaksaan pembelajaran siswa juga diberi waktu untuk aktif dalam beranya, akan tetapi hasilnya pembelajaran tetaplah kurang aktif. Hal ini dapat dilihat dari nilai siswa pada kelas eksperimen dan kelas kontrol.

Hasil pretest menunjukan bahwa nilai tertinggi kelas eksperimn dengan kelas kontrol adalah sama 85, begitu juga dengan nilai terrendahnya, kelas eksperimen dan kelas kontrol mmiliki nilai rendah 50. Meskipun kedua kelas tersebut memiliki nilai tertinggi dan terendah sama, namun nilai rata-ratanya berbeda. Hal ini dikarenakan pada kelas eksperimen siswa yang mendapatkan nilai tinggi sdikit dibandingkat pada kelas kontrol. Nilai rata-rata kelas eksperimen adalah 67,56 sedangkan nilai rata-rata kelas kontrol 67,73. ini menunjukan bahwa adanya perbedaan kemampuan antara kedua kelas eksperimen dengan kelas kontrol namun kesua kelas masih memiliki variansi yang homogeny ditunjukan oleh hasil uji homogennitas 
varians diantara keduanya yang memberikan hasil bahwa kedua kelas adalah homegen, sehingga kedua kela masih memenuhi untuk dijadikan sebagai sampel penelitian.

Sedangkan hasil post-test menunjukan bahwa nilai tertinggi dan terendah yang dicapai oleh iswa pada kelas eksperimen secara berurutan adalah 100 dan 50 dengan nilai rata-rata 68,60 sedangkan nilai tertinggi dan terendah yang dicapat oleh kelas kontrol secaraberturutturut adalah 90 dan 50 dengan nilai rata-rata 68,40. dilihat dari rata-rata hasil pretest dan post-test masing-masing kels didapatkan bahwa kelas eksperimen mengalami kenaikan yang cukup besar dibandingkan dengan kelas kontrol.

Setelah dilakukannya perhitungan dengan menggunakan uji-r maka diperoleh nilai $r_{\text {hitung }}=0,925$ kemidian nilai tersebut dibandingkan dengan nilai $r_{\text {tabel }}$ dengan $\mathrm{n}=23$ dan taraf signifikan 5\%=0,396. Karena harga $r_{\text {hitung }}>r_{\text {tabel }}$ maka $\mathrm{H}_{0}$ ditolak dan $\mathrm{H}_{\mathrm{a}}$ diterima, dengan demikian dapat terdapat pengaruh antara pendekatan open-ended dan kemampuan berpikir kreatif pada uji hipotesis.

Uji regresi yang dilakukan terhadap hasil pretest dan post-tets pada kelas eksperimen menunjukan adanya perbedaan hasil yang cukup signifikan antara sebelum dan sesudah diberi perlakuan, setelah dilakukan perhitungan diperoleh hasi nilai $r_{\text {hitung }}=0,925$ sedangkan nilai $r_{\text {tabel }}=0,396$ karena $r_{\text {hitung }}>r_{\text {tabel }}$ maka $\mathrm{H}_{0}$ ditolak dan $\mathrm{H}_{\mathrm{a}}$ diterima, dengan demikian dapat ditarik kesimpulan bahwa kemampuan berpikir kreatif siswa sesudah diberikan perlakuan lebih baik dari pada sebelum diberi perlakuan. Dengan kata lain terdapat pengaruh antara pendekatan open-ended dan kemampuan berpikir kreaif.

Pembelajaran dengan menggunakan pendekatan open-ended siswa lebih aktif, siswa jadi lebih bertanggung jawab terhadap tugasnya, siswa menjadi lebih tahu inti dari pembelajaran ang mereka lakukan dengan adanya kesimpulan, siswa menjadi lebih mampu dalam menyelesaikan masalah-masalah yang berkaitan dengan materi, serta kesan senang dlam pembelajran lebih terlihat. Sedangakn pembelajran dengan menggunakan pmbelajaran kooperatif tipe STAD siswa menjadi kurang aktif, banyak siswa yang menjukkan sikap bosan karena harus mengerjakan soal, terlebih lagi bagi siswa yang memiliki kemampuan rendah, meskipun dalam pelaksaan pembelajaran siswa juga diberi waktu untuk aktif dalam beranya, akan tetapi hasilnya pembelajaran tetaplah kurang aktif. Hal ini dapat dilihat dari nilai siswa pada kelas eksperimen dan kelas kontrol.

Uji regresi yang dilakukan terhadap hasil angket kepercayaan diri pada kelas eksperimen menunjukan adanya perbedaan hasil yang cukup signifikan antara sebelum dan sesudah diberi perlakuan, setelah dilakukan perhitungan diperoleh hasil nilai $r_{\text {hitung }}=$ 0,907 sedangkan nilai $r_{\text {tabel }}=0,396$ karena $r_{\text {hitung }}>r_{\text {tabel }}$ maka $\mathrm{H}_{0}$ ditolak dan $\mathrm{H}_{\mathrm{a}}$ diterima, kepercayaan diri diperoleh hasil nilai $r_{\text {hitung }}=0,907$ sedangkan nilai $r_{\text {tabel }}=$ 0,396 karena $r_{\text {hitung }}>r_{\text {tabel }}$ maka $\mathrm{H}_{0}$ ditolak dan $\mathrm{H}_{\mathrm{a}}$ diterima, dengan demikian dapat ditarik kesimpulan bahwa kepercayaan diri siswa sesudah diberikan perlakuan lebih baik dari pada sebelum diberi perlakuan. Dengan kata lain terdapat pengaruh antara pendekatan openended dan kepercayaan diri. 


\section{SIMPULAN}

Setelah dilaksanakannya penelitian serta berdasarkan analisis data dan penguji hipotesis dapat diambil kesimpulan bahwa : terdapat pengaruh pendekatan open-ended terhadap kemampuan berpikir kreatif pada materi SPLDV dikelas X SMK Putra Anda Binjai. Berdasarkan hasil perhitungan yang dilakukan diperoleh hasil nilai $r_{\text {hitung }}=0,925$ sedangkan nilai $r_{\text {tabel }}=0,396$ karena $r_{\text {hitung }}>r_{\text {tabel }}$ maka $\mathrm{H}_{0}$ ditolak dan $\mathrm{H}_{\mathrm{a}}$ diterima dalam kemampuan berpikir kreatif.

Berdasarkan hasil analisis data dan penguji hipotesis yang telah dilakukan, maka kepercayaan diri diperoleh hasil nilai $r_{\text {hitung }}=0,907$ sedangkan nilai $r_{\text {tabel }}=0,396$ karena $r_{\text {hitung }}>r_{\text {tabel }}$ maka $\mathrm{H}_{0}$ ditolak dan $\mathrm{H}_{\mathrm{a}}$ diterima, dengan demikian dapat ditarik kesimpulan bahwa : terdapat pengaruh antara pendekatan open-ended terhadap kepercayaan diri pada materi SPLDV dikelas X SMK Putra Anda Binjai.

\section{REFERENSI}

Arikunto, Suharsimi, Prosedur Penelitiasn Suatu Pendekatan Praktik, Jakarta : PT Rineka Cipta, edisi revisi 2010

Cahyaningsih, Restu \& Asikin, M. Komparasi Kemampuan Berpikir Kreatif. Jurnal Nalar Pendidikan, No.1 Volume 3, Januari - Juni 2015

Farhan, Abu, Rasa Kepercayaan Diri Tinggi, (Bali : Undiksha Press), Tahun, 2012.

Sugiyono. Metode Penelitian Kuantitatif Kualitatif Dan R\&D, Bandung : Alfabeta, 2012

Sudjana, Metode Statistika, Bandung: Tarsito, 2005. 